\title{
職業性尿路腫瘍の臨床的研究
}

\author{
自治医科大学泌尿器科学教室（主任：徳江章彦教授） \\ 石山俊次
}

\section{CLINICAL STUDY ON OCCUPATIONAL UROEPITHELIAL CANCER}

\author{
Shunji Ishiyama \\ Department of Urology, Jichi Medical School
}

(Director: Prof. A. Tokue)

We experienced 32 cases of occupational uroepithelial cancer at Jichi Medical School Hospital from 1974 to 1990. All of them were dyestuff workers who had been engaged in production or handling of benzidine, $\beta$-naphthylamine or $\alpha$-naphthylamine. In these 32 cases, upper urinary tract tumors were found in 7 cases, one of these having bilateral lesions.

The mean age when the tumor of the urinary tract was first disclosed was 48 years old, with a range of 36 to 66 years old. The mean age of this occupational group was about 16 years younger than that of the spontaneous urinary tract tumor group in our hospital.

We divided our cases into two groups according to duration of carcinogen exposure; less than 5 years and 5 years or more. However we did not obtain significant difference in the grade of tumors or prognosis between the two groups.

But when we divided them into two groups according to the type of work; production group and handling group, 18 of 21 production workers had high grade tumors. On the other hand, only 3 of 11 handling workers had high grade tumors, which was a significant difference. Besides, 10 of 21 production workers or only one of 11 handling workers were fatal. The difference was also significant.

There was no significant correlation among the type of work, the duration of exposure and the age of onset.

In our study, we showed that the type of work was quite important to predict the grade of tumors and the prognosis in occupational uroepitherial cancer patients.

Our data indicate that close observation is necessary especially for the group of workers who had been engaged in production of carcinogenic aromatic amines.

Key words: occupational uroepitherial cancer, exposure of carcinogen, type of work

\begin{abstract}
要旨：1974年 4 月〜1990年 3 月の 16 年間に自治医科大学泌尿器科学教室で経験した 32 例の職業性尿路畽 瘍患者を対象として, 各症例の発癌物質曝露状況と発生した腫瘍の病理組織所見, 臨床経過, 予後との 関係を中心に詳細な検討を行った。症例は全て染料工場従業員で，発癌性芳香族アミンの製造あるいは 取扱いに従事していた.製造工程と取扱い工程では発癌物質の曝露量にかなりの差があったと考えられ， 32例を携わった作業内容により製造群と取扱い群の 2 群に分け検討すると, 製造群では high grade 腫場 の発生数, 死亡数とも取扱い群より有意に高かった。また重複癌や特異な病理組織像を呈する腫瘍の発 生も製造群にのみみとめられた。 これらの所見は発癌物質の dose-effect の現れと考えられ, 発癌性芳香 族アミンの製造に従事した者では，今後の経過観察，治療方針の決定について特に注意が必要である. キーワード：職業性尿路腫瘍, 発癌物質曝露, 作業内容
\end{abstract}

\section{緒 言}

benzidine(以下 BZ), $\beta$-naphthylamine(以下 $\beta \mathrm{NA}$ ) などの芳香族アミンによる職業性尿路腫場は，これら
の化合物が染料の中間体として使用されたことから， 主として染料工場従事者に発生した。わが国では1972 年, 労働安全衛生法の施行により, これらの発癌物質 
の製造，使用が禁止されたが，その後も患者の発生は 続いている。1988年, 日本泌尿器科学会中部総会のシ ンポジゥムで，わが国における職業性尿路腫瘍の現時 点での総括がなされ，一つの区切りを迎えたと思われ るが，診療にあたっている医療機関が限られて捛り， 臨床的検討の報告は少なく，特に個々の症例の曝露状 況と発生した腫瘍の病理組織所見，臨床経過，予後と の関係について詳細に検討した論文はほとんぞ見られ ない.

われわれの教室では，1974年 4 月の開講以来，関西 地区にある 4 つの化学工場で発生した職業性尿路腫瘍 患者の診療にあたってきたが，1990年 3 月までの16年 間に経験した患者数は，大分県，神奈川県の工場で発 生した各 1 例を加えて，計 32 例になる．今回，これら の症例を対象に臨床的検討を行ったが，特に発癌物質 の曝露状況と発生した腫瘍の異型度, 臨床経過, 予後 との関係を中心に, 個々の症例について詳細に検討し， 若干の知見が得られたので文献的考察を加えて報告す る.

\section{対象および方法}

1. 対象：関西地区の $\mathrm{A}, \mathrm{B}, \mathrm{C}, \mathrm{D}$, 神奈川県の $\mathrm{E}$, 大分県の $\mathrm{F}$ の 6 つ化学工場で, $\mathrm{BZ}, \beta \mathrm{NA}$, および $\alpha$-naphthylamine（以下 $\alpha \mathrm{NA}$ ) に懪露した既往があ り, 病理組織学的に尿路上皮癌と確認された 32 例を対 象とした. 工場別では, A 工場19例，B工場 6 例，C工 場 3 例，D工場 2 例，E，F工場各 1 例であった。 A 工 場では $\mathrm{BZ}, \beta \mathrm{NA}$ の製造と，これらを使った染料の製 品化までが行われており，従業員の作業内容は，製造 と取扱いに分けられた。 B, C, D の 3 つの工場では BZ の製造のみ, $\mathrm{E} 工$ 場では $\beta \mathrm{NA}, \mathrm{F}$ 工場では $\alpha \mathrm{NA}$ の製 造のみが行われていた。

2. 検討項目：32例について曝露物質, 曝露開始年次 および年齢，曝露期間，発病年齢，潜伏期間，初発症 状(診断のきっかけ), 腫瘍発生部位, 腫瘍の病理組織 所見, 治療法, 再発の回数, 重複癌の発生, 予後なぞ を検討した，同時期にわれわれの教室で経験した自然 発生尿路腫瘍症例のうち，男性例との比較検討も行っ たＡ工場で発生した19例については工場側の協力を 得て, 作業内容を詳細に調へ，発生した腫瘍の悪性度 や臨床経過，予後などとの関係を検討した。有意差検 定は年齢の検討のみ $\mathrm{t}$ 検定，他はすべてカイ 2 乗検定 を使用した。

手術による摘出標本のある症例では, 組織パラフィ ンブロックをミクロトームにて薄切, $30 \sim 50 \mu$ 切片を
作成し, 脱パラフィン水和処理した後 trypsin にて裸 核処理し， propidium iodine にてDNA を染色，flow cytometer にてDNA ヒストグラムを作成した。 ヒス トグラムの作成は, 大塚アッセイ研究所にて行った。

\section{結 果}

32 例の曝露物質, 曝露開始年次および年齢, 曝露期 間，発病年齢，潜伏期間，初発症状(診断のきっかけ), 腫瘍発生部位, 腫瘍の病理組織学的所見, 治療法, 再 発回数, 重複癌の発生, 予後を Table 1-a および 1-b に示した，曝露期間は上記 3 つ発癌物質の製造ある いは取扱いに従事していた期間とした。腫瘍の病理組

Table 1-a Summary of occupational urinary tract tumor patients (epidemiologic profiles)

\begin{tabular}{r|c|c|l|c|l}
\hline $\begin{array}{c}\text { Pt } \\
\text { No. }\end{array}$ & $\begin{array}{l}\text { Year(Age) } \\
\text { started } \\
\text { working }\end{array}$ & $\begin{array}{c}\text { Com- } \\
\text { pound }\end{array}$ & $\begin{array}{l}\text { Duration } \\
\text { of } \\
\text { exposure }\end{array}$ & $\begin{array}{c}\text { Age } \\
\text { of } \\
\text { onset }\end{array}$ & $\begin{array}{l}\text { Latent } \\
\text { period }\end{array}$ \\
\hline 1 & $1946(24)$ & $\mathrm{BZ}$ & $12 \mathrm{y}$ & 44 & $20 \mathrm{y} 6 \mathrm{Mo}$ \\
2 & $1951(28)$ & $\beta \mathrm{NA}$ & $6 \mathrm{y} 8 \mathrm{Mo}$ & 48 & $19 \mathrm{y} 10 \mathrm{M}$ \\
3 & $1948(26)$ & $\mathrm{BZ}$ & $15 \mathrm{y} 1 \mathrm{Mo}$ & 44 & $16 \mathrm{y} 7 \mathrm{Mo}$ \\
4 & $1951(29)$ & $\mathrm{BZ}$ & $11 \mathrm{y} 9 \mathrm{Mo}$ & 48 & $18 \mathrm{y} 7 \mathrm{Mo}$ \\
5 & $1950(33)$ & $\mathrm{BZ}$ & $9 \mathrm{y}$ & 49 & $15 \mathrm{y} 11 \mathrm{Mo}$ \\
6 & $1947(37)$ & $\mathrm{BZ}$ & $3 \mathrm{y} 1 \mathrm{Mo}$ & 54 & $16 \mathrm{y} 9 \mathrm{Mo}$ \\
7 & $1949(34)$ & $\mathrm{BZ}$ & $13 \mathrm{y} 5 \mathrm{Mo}$ & 48 & $13 \mathrm{y} 9 \mathrm{Mo}$ \\
8 & $1948(29)$ & $\beta \mathrm{NA}$ & $8 \mathrm{y} 4 \mathrm{Mo}$ & 38 & $9 \mathrm{y} 6 \mathrm{Mo}$ \\
9 & $1948(45)$ & $\beta \mathrm{NA}$ & $12 \mathrm{y} 5 \mathrm{Mo}$ & 56 & $10 \mathrm{y} 7 \mathrm{Mo}$ \\
10 & $1950(33)$ & $\mathrm{BZ}$ & $10 \mathrm{Mo}$ & 56 & $22 \mathrm{y} 1 \mathrm{Mo}$ \\
11 & $1954(21)$ & $\mathrm{BZ}, \beta \mathrm{NA}$ & $1 \mathrm{y} 5 \mathrm{Mo}$ & 40 & $19 \mathrm{y} 5 \mathrm{Mo}$ \\
12 & $1947(31)$ & $\mathrm{BZ}$ & $15 \mathrm{y} 11 \mathrm{Mo}$ & 56 & $25 \mathrm{y}$ \\
13 & $1948(25)$ & $\beta \mathrm{NA}$ & $8 \mathrm{y} 4 \mathrm{Mo}$ & 44 & $18 \mathrm{y} 9 \mathrm{Mo}$ \\
14 & $1947(24)$ & $\beta \mathrm{NA}, \mathrm{BZ}$ & $14 \mathrm{y} 1 \mathrm{Mo}$ & 47 & $23 \mathrm{y} 3 \mathrm{Mo}$ \\
15 & $1954(38)$ & $\beta \mathrm{NA}$ & $6 \mathrm{y} 5 \mathrm{Mo}$ & 61 & $22 \mathrm{y} 7 \mathrm{Mo}$ \\
16 & $1954(21)$ & $\mathrm{BZ}, \beta \mathrm{NA}$ & $4 \mathrm{y} 1 \mathrm{Mo}$ & 47 & $26 \mathrm{y}$ \\
17 & $1954(20)$ & $\mathrm{BZ}$ & $3 \mathrm{y} 6 \mathrm{Mo}$ & 36 & $15 \mathrm{y} 7 \mathrm{Mo}$ \\
18 & $1954(35)$ & $\mathrm{BZ}$ & $1 \mathrm{y} 2 \mathrm{Mo}$ & 64 & $29 \mathrm{y}$ \\
19 & $1962(25)$ & $\mathrm{BZ}$ & $2 \mathrm{Mo}$ & 43 & $28 \mathrm{y} 5 \mathrm{Mo}$ \\
20 & $1961(17)$ & $\mathrm{BZ}$ & $10 \mathrm{y}$ & 37 & $20 \mathrm{y}$ \\
21 & $1962(29)$ & $\mathrm{BZ}$ & $10 \mathrm{y}$ & 39 & $10 \mathrm{y}$ \\
22 & $1962(23)$ & $\mathrm{BZ}$ & $4 \mathrm{y}$ & 42 & $19 \mathrm{y} 1 \mathrm{Mo}$ \\
23 & $1963(29)$ & $\mathrm{BZ}$ & $2 \mathrm{y} 7 \mathrm{Mo}$ & 42 & $13 \mathrm{y} 6 \mathrm{Mo}$ \\
24 & $1968(25)$ & $\mathrm{BZ}$ & $3 \mathrm{y} 5 \mathrm{Mo}$ & 39 & $14 \mathrm{y} 2 \mathrm{Mo}$ \\
25 & $1964(27)$ & $\mathrm{BZ}$ & $1 \mathrm{y}$ & 45 & $18 \mathrm{y} 4 \mathrm{Mo}$ \\
26 & $1965(52)$ & $\mathrm{BZ}$ & $6 \mathrm{y} 8 \mathrm{Mo}$ & 66 & $13 \mathrm{y} 10 \mathrm{Mo}$ \\
27 & $1960(18)$ & $\mathrm{BZ}$ & $1 \mathrm{y}$ & 41 & $23 \mathrm{y}$ \\
28 & $1945(23)$ & $\mathrm{BZ}$ & $1 \mathrm{y} 8 \mathrm{Mo}$ & 52 & $28 \mathrm{y} 8 \mathrm{Mo}$ \\
29 & $1949(43)$ & $\mathrm{BZ}$ & $5 \mathrm{y} 4 \mathrm{Mo}$ & 60 & $17 \mathrm{y} 4 \mathrm{Mo}$ \\
30 & $1954(18)$ & $\mathrm{BZ}$ & $1 \mathrm{y} 2 \mathrm{Mo}$ & 36 & $18 \mathrm{y}$ \\
\hline 1 & $1948(23)$ & $\beta \mathrm{NA}$ & $4 \mathrm{y} 1 \mathrm{Mo}$ & 50 & $27 \mathrm{y} 2 \mathrm{Mo}$ \\
$\mathrm{B}=$ & $1951(29)$ & $\alpha \mathrm{NA}$ & $17 \mathrm{y} 2 \mathrm{Mo}$ & 64 & $24 \mathrm{y} 11 \mathrm{Mo}$ \\
\hline
\end{tabular}

$\mathrm{B}=$ benzidine $\quad \beta \mathrm{NA}=\beta$-naphthylamine $\alpha \mathrm{NA}=\alpha$-naphthylamine 
Table 1-b Summary of occupational urinary tract tumor patients (Clinical course)

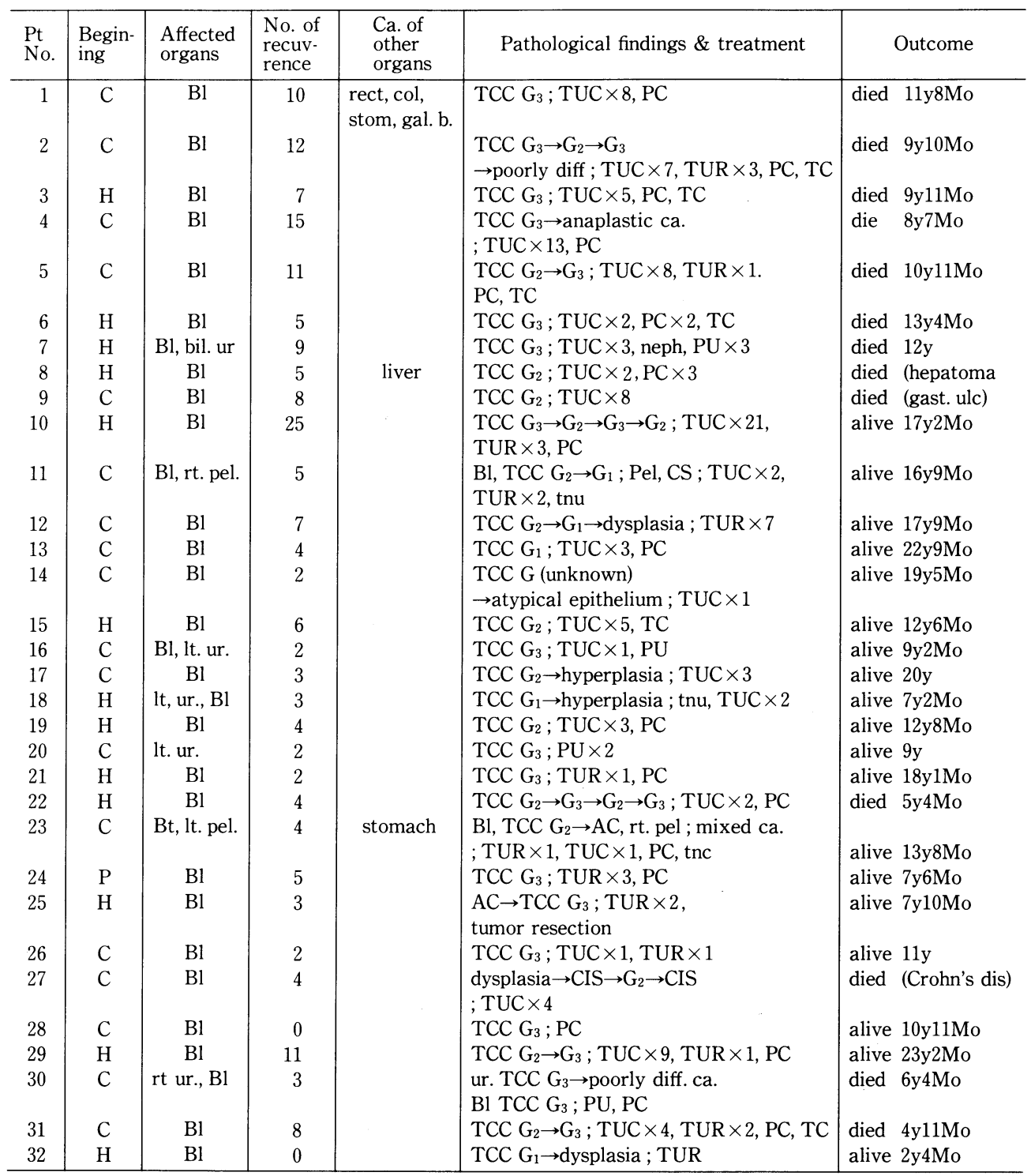

$\mathrm{Bl}=$ bladder, $u r=$ ureter, pel. = pelvis, $\mathrm{C}=$ cytology, $\mathrm{P}=$ pollakisuria, $\mathrm{CS}=$ carcinosarcoma, tnu $=$ total nephroureterectomy, $\mathrm{PU}=$ partial ureterectomy, $\mathrm{H}=$ hematuria, rect $=$ rectum, $\mathrm{col}=$ colon, stom $=$ stomach, gal.b. $=$ gall bladder

織学的所見とその経過は, 発生した腫瘍の部位と grade に変化があった場合, それを順に記載した。

同時期に当教室で経験した自然発生尿路腫瘍症例の らち，男性例の総括を上部尿路腫瘍と膀胼腫痬に分け て Table 2 に示した。

1）労動衛生学的検討 :

1. 曝露物質：32例中 $\mathrm{BZ}$ に曝露したものが 22 例と
Table 2 Spontaneous urinary tract tumors (1974. 4 1990.3)

\begin{tabular}{l|c|c|c}
\hline & bladder & upper tract & total \\
\hline No. of pts (\%) & $276(90.8)$ & $28(9.2)$ & $304(100)$ \\
mean age of onset (range) & $64.3(26 \sim 88)$ & $64.3(50 \sim 82)$ & $64.3(26 \sim 88)$ \\
gross hematuria (\%) & $227(82.2)$ & $25(89.3)$ & $252(82.9)$ \\
high grade tumor (\%) & $90(28.6)$ & $12(42.9)$ & $102(33.6)$ \\
total cystectomy (\%) & $100(36.2)$ & & \\
\hline
\end{tabular}


最も多く,ついで $\beta \mathrm{NA}$ が 6 例, $\mathrm{BZ}, \beta \mathrm{NA}$ の両方が 3 例， $\alpha \mathrm{NA}$ が 1 例であった。

2. 曝露期間： 2 力月 17 年 2 力月, 平均 6 年 9 力 月, 曝露物質別では $\mathrm{BZ}$ は 2 力月 15 年11力月, 平均 6 年, $\beta \mathrm{NA}$ は 4 年 1 力月 12 年 5 力月, 平均 7 年 9 力月 であった。 $\mathrm{BZ}, \beta \mathrm{NA}$ 両方の製造に従事した 3 例は, 全て BZ に曝露された期間の方が長かったが， 1 年 5 カ月 14年 1 カ月, 平均 6 年 6 力月であった。 $\alpha \mathrm{NA}$ は 17年 2 カ月と曝露期間では最も長かった。

3. 潜伏期間 : 最短 9 年 6 力月, 最長 34 年 11 力月で, 平均 19 年 5 力月, 曝露物質別では, $\mathrm{BZ}$ は 10 年 29 年, 平均 19 年 1 力月, $\beta \mathrm{NA}$ は 9 年 6 力月 27 年 2 力月, 平 均18年 1 カ月と, 両方の間に大きな差はみとめられな かった. $\mathrm{BZ}, \beta \mathrm{NA}$ 両方に暴露された 3 例では 19 年 5 カ月 26年, 平均 22 年10力月とやや長く, $\alpha$ NA では 34 年11カ月と最も長い潜伏期間を示した。

2) 臨床的検討

1. 発病年齢：初発時の年龄は36歳から66歳にわた ク, 平均48歳であった (Table 3).40歳台にピークを みとめ, 50 歳未満の症例が 21 例 $(63.6 \%)$ と半数以上 を占めていた。 20 歳台に曝露開始し，40歳台に発病し たものが12例（37.5\%）で最も多かった。

2. 初発症状（診断のきっかけ）：血尿を初発症状と したものは13例 (40.6\%), 他に膀胱刺激症状が 1 例 あったが，スクリーニングの尿細胞診で異常を指摘さ れて, 精査の結果尿路腫瘍が発見されたものが18例 (56.3\%) と, 半数以上で細胞診が診断のきっかけに なっていた。

3. 腫瘍発生部位：膀胱のみ 24 例 (75\%), 膀胼およ び上部尿路 7 例 (21.9\%), 上部尿路のみ 1 例 (3.1\%) であった。膀胱，上部尿路の両方に腫浧発生をみた 7 例のうち, 上部尿路腫掦の発生が膀朕腫瘍よりも先行 したものは 2 例のみで, 5 例は膀胼腫瘍が先行し, 経 尿道的手術あるいは膀脱部分切除術施行後, $2 \sim 20$ 年 を経て上部尿路に腫瘍の発生をみている。

Table 3 Age of onset

\begin{tabular}{|c|c|c|}
\hline $30-39^{1)}$ & $6^{2)}$ & $(18.8)^{3)}$ \\
\hline $40-49$ & 15 & $(46.9)$ \\
\hline $50-59$ & 6 & (18.8) \\
\hline $60-69$ & 5 & (15.6) \\
\hline total & 32 & (100) \\
\hline
\end{tabular}

4. 再発回数：0２5回, 平均 6.3回. 死亡例 12 例(平 均再発回数 8.1 回)を除いた生存例 20 例の平均再発回数 は5.2回であった。

5. 治療法: 経尿道的手術（TUR-Bt あるいは

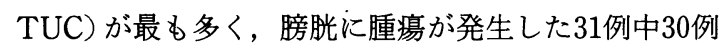
(96.8\%)に施行されていた。次に多かったのは膀胱部 分切除術で，17例（54.8\%）に延べ20回施行されてい た。膀胼全摘除術は 6 例（19.4\%）に施行された。そ のらち 5 例は膀胱部分切除術後に施行されたが，全例 死亡した。

6. 重複癌： 3 例 (9.4\%) にみられた。 1 例は直腸 癌, 胃癌, 胆衰癌, 結腸癌と合わせて五重癌であった。 他に肝臓癌 1 例, 胃癌 1 例であった.

7. 自然発生尿路腫瘍との比較検討：同時期に当教 室で経験した自然発生尿路腫瘍の男性例は304例で あった(Table 2). 初発年跉は, 26歳 88歳, 平均 64.3 歳で, 職業性尿路腫瘍症例の発症年齢は約16年若く, その差は有意であった $(\mathrm{p}<0.001)$.

初発症状としての肉眼的血尿の頻度は職業性群で $39.4 \%$ であるのに比べ，自然発生群では $82.9 \%$ と有意 に高率であった $(\mathrm{p}<0.01)$.

部位別では, 膀胱腫瘍276例 (90.8\%), 上部尿路腫 瘍 28 例 $(9.2 \%)$ で，職業性群での上部尿路腫瘍の発生 率（25\%）が有意に高かった（p<0.01）.

発生した腫瘍が high grade（grade 3）であったの は, 自然発生群102例(33.6\%), 職業性群21例(65.6\%) と, 職業性群に異型度の高い腫瘍が多くみとめられた $(\mathrm{p}<0.01)$.

治療法で膀胱全摘除術が施行されたのは，自然発生 膀胼腫瘍276例中 100 例 (36.2\%), 職業性膀胱腫瘍31例 中 6 例 (19.4\%), で, 職業性群では膀胖保存の術式が 選択される傾向がみとめられた。

3）曝露状況と発生した腫瘍の異型度, 臨床経過, 予 後との関係についての検討

1. 作業内容による曝露量の差異：A工場における $\mathrm{BZ}$ および $\beta \mathrm{NA}$ の製造から製品化にいたる工程は, 1. $\mathrm{BZ}$ ベースの製造, b. 同乾燥, c. 同配合, d. $\beta \mathrm{NA} の$ 製造および乾燥の 4 つの部門にわかれており，それぞ れは独立した建物内で行われていた。 a 工程は, 出来上 がった BZに直接接触する機会が最も多く, 特に労働 環境が改善された1956年までは保護具もマスク以外は ほとんどなく，曝露量はかなり大量であったと推測さ れる (症例 $1,3,4,6,7$ ).

$\mathrm{b}$ 工程も $70 \sim 80^{\circ} \mathrm{C}$ の高温で乾燥させることにより, 
$\mathrm{BZ}$ の粉塵が大量に発生し, $\mathrm{a} 工$ 工程同様, 曝露量は多 かったと考兄られる(自験例には該当症例なし)。また， 担当者によると，両工程とも労働時間内はほぼ同じ作 業を続けて拈り，工場内が高温であることから，上半 身は裸で作業していたものも多かったとのことであっ た。これに対してC工程の作業者は，1 日 2 回，各30 分〜 1 時間ほど出来上がった製品の取扱いに従事して いたのみで, 直接接触する $\mathrm{BZ}$ の量が少なく, 粉塵の影 響もないので, $\mathrm{a}, \mathrm{b}$ 工程の作業者に比べて曝露量は著 しく少なかったものと考学られる（症例 $5 ， 10 ， 17$, 18, 19). d 工程の作業者は $\mathrm{a}, \mathrm{b}$ と同様, 発癌物質に直 接接触している時間が長く, 曝露量もかなり大量で

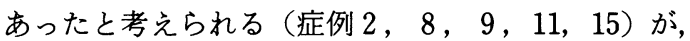
この建物内では，製造に従事していた者の他，出来上 がった $\beta \mathrm{NA}$ の取扱いのみを担当していた者（症例13， 14，16）もあり，同じ工程でも曝露量はかなりの差が あったと考えられた，B〜Eの 4 工場では製造工程の みが行われていたが，A工場に比べて規模が小さいた め, 労働環境も後年まで悪く, 曝露量は $\mathrm{A}$ 工程の製造 者と同様，あるいはそれ以上のかなり大量であったと 考兄れた(症例20～26，28～31)．但し，C工場の症 例27は製造に直接携わったのではなく，主として倉庫 内の仕事であり，曝露量は少なかったと考兄られた。 $\mathrm{F}$ 工場で製造されていた $\alpha \mathrm{NA}$ には1972年まで 6 〜 $7 \%$ \% $\beta \mathrm{NA}$ が含まれていた（1972年以降は $1 \%$ 以 下). 後述するように $\alpha \mathrm{NA}$ 自体には発癌性がないとさ れていることから, 発癌が $\beta$ NAによるものとすると, 曝露量はきわめて少量と考号られる(症例32)．以上の ことから自験例32例は作業内容から，同じ曝露期間で 子曝露量の多い群(製造群：症例 $1 \sim 4,6 \sim 9,11$,
15，20～26，27～31）と少ない群（取扱い群：症例 5, 10，12１4，16１9，27，32）に分けられ，その曝露 量の差はかなり大きいと考兄られた。

2. 曝露期間, 曝露量と臨床経過：32例を曝露期間の 長さによって， 5 年末満， 5 年以上の 2 群に分け, 発 生した腫湯の異型度（最も高いもの）, 予後をみると Table 4 のごとくになる．5 年末満15例の中で grade 3の腫崵が発生したのは11例（73.3\%), 死亡したのは 4 例 (26.7\%) であった。 5 年以上 17 例では, grade 3 10例 (58.8\%), 死亡 7 例 (41.1\%)であり, high grade 腫瘍の発生, 死亡とも両群間に有意の差はみとめな かった.

次に，携わった業務により製造と取扱いの 2 群に分 けて異型度および予後をみると, grade 3の腫湯発生 は，製造者21例中18例（85.7\%）と高率にみられ，取 扱い者では11例中 3 例（27.3\%）で，製造者は取扱い 者に比べて high grade の腫場発生が多くみとめられ た（p<0.01）。死亡例は製造者21例中10例 $(47.6 \%)$ ， 取扱い者 11 例中 1 例 $(9.1 \%)$ と製造者に予後不良のも のが多かった $(\mathrm{p}<0.05)$ （Table 5)。 また，両群間で 曝露期間, 発病年龄, 潜伏期間を比較すると, 潜伏期 間が取扱い群で有意に長かった $(\mathrm{p}<0.01)$ が，作業内 容と曝露期間，発病年齢との間には有意の関係をみと めなかった（Table 6).

3. flow cytometryによる腫瘍悪性度の評価：摘出 標本で flow cytometryによるDNA ヒストグラムの 作成ができたのは，16例，18検体についてであった(症 例 $1 \sim 6,11,16,20,21,22,23,25,29,30,31$ ).

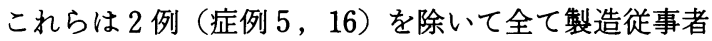
であった。病理組織学的には, 移行上皮癌 grade $3 か ゙ 15$

Table 4 Relationship among duration of exposure, tumor grade and prognosis

\begin{tabular}{c|c|c|c}
\hline duration of exposure & No. of pts. & high grage tumor (\%) & died pts. (\%) \\
\hline less than 5yrs & 15 & $11(73.3$ & $4(26.7)$ \\
5yrs or more & 17 & $10(58.8)$ & $7(41.1)$ \\
total & 32 & $21(65.6)$ & $11(34.9)$ \\
\hline
\end{tabular}

Table 5 Relationship among type of work, tumor grade and prognosis

\begin{tabular}{c|c|c|c}
\hline type of work & No. of pts. & *high grade tumor (\%) & ${ }^{* *}$ died pts. (\%) \\
\hline production group & 21 & $18(85.7)$ & $10(47.6)$ \\
handling group & 11 & $3(27.3)$ & $1(9.1)$ \\
total & 32 & 21 & $11^{*}$ \\
\hline \multicolumn{2}{|r}{}
\end{tabular}


Table 6 Relationship among type of work, duration of exposure,

age of onset and latent period

\begin{tabular}{c|c|c|c}
\hline type of work & $\begin{array}{c}\text { duration of exposure } \\
(\text { mean })\end{array}$ & $\begin{array}{c}\text { age of onset } \\
\text { (mean) }\end{array}$ & $\begin{array}{c}{ }^{*} \text { latent period } \\
\text { (mean) }\end{array}$ \\
\hline production group & $\begin{array}{c}\mathrm{y} \sim 15 \mathrm{y} 1 \mathrm{Mo} \\
(6 \mathrm{y} 3 \mathrm{Mo})\end{array}$ & $\begin{array}{c}36 \sim 66 \\
(47.1)\end{array}$ & $\begin{array}{c}9 \mathrm{y} 6 \mathrm{Mo} \sim 28 \mathrm{y} 8 \mathrm{Mo} \\
(17 \mathrm{y} 6 \mathrm{Mo})\end{array}$ \\
handling group & $\begin{array}{c}10 \mathrm{Mo} \sim 17 \mathrm{y} 2 \mathrm{Mo} \\
(6 \mathrm{y} 10 \mathrm{Mo})\end{array}$ & $\begin{array}{c}36 \sim 64 \\
(49.7)\end{array}$ & $\begin{array}{c}15 \mathrm{y} 7 \mathrm{Mo} \sim 34 \mathrm{y} 11 \mathrm{Mo} \\
(24 \mathrm{y} 2 \mathrm{Mo})\end{array}$ \\
\hline \multicolumn{2}{|c}{}
\end{tabular}

症例16検体とほとんどを占め, 他に, 癌肉腫, 混合型 癌が 1 検体づつであった. DNA ヒストグラムでは全 例 aneuploid patternを示した。

aneuploidy DNA の peak channel 值と 2 倍体細胞 DNA の peak channel 值との比率を DNA index (DI) とすると, 18 検体の DI は $1.26 \sim 2.20$, 平均 1.60 であっ た.

\section{考 察}

$\mathrm{BZ}, \beta \mathrm{NA}$ などの芳香族アミンによる職業性尿路腫 瘍は，これらの発癌物質が染料の中間体として広く使 われたことから，主として染料工場の従業員に発生し た。ドイッにおける Rehn（1895）の報告1)以来，スイ ス，イギリス，フランス，イタリア，ソ連などのヨー ロッパ先進国やアメリカ，日本の他，オーストリア， ポーランド，チェコスロバキア，インドなどでも多く の職業性尿路腫煌患者の発生が報告されている21.

わが国では，ヨーロッパ各国よりやや遅れて，1972 年に労働安全衛生法により, $\mathrm{BZ}, \beta \mathrm{NA}, 4$-aminobiphenyl, 4-nitrobiphenyl などの製造および取扱いは禁 止されたが，それから18年以上経過した現在でも新た な患者の発生がみられている。 $\alpha$ NA については, それ 自体には発癌性はないとされ, 発癌は不純物として混 じる $\beta \mathrm{NA}$ にるるのと考光られており， $\beta \mathrm{NA}$ を $1 \%$ 以上含有するものはやはり製造および取扱いが禁止さ れている31.

職業性尿路腫瘍患者の診療にあたっている医療機関 は, 疾患の社会的性質上比較的少なく，1988年の日本 泌尿器科学会中部総会シンポジゥムでも, 臨床的検討 の報告は, 九州 ${ }^{3)}$, 関西45), 東京 ${ }^{677)}$ の限られた施設から のみであった。

われわれの教室でも1990年 3 月までに診療にあたっ た職業性尿路腫瘍患者は32例となり, 各症例の曝露状 況, 発生した腫瘍の病理所見, 臨床経過を詳細に検討 した，今回われわれの検討でも，職業性腫瘍では自然 発生腫瘍と比較して, 発病年齢がかなり低いこと, 診
断のきっかけとしてスクリーニングの尿細胞診が重要 な位置をしめていること, 上部尿路腫場の発生率が高 いこと, 膀胼全摘除術を施行された症例が少ないこと などは従来の報告と同様であった。発病年齢が低いの は, 尿路に限らず職業癌に共通した特徵であり, 曝露 年齢が早ければ早いほど若年で発癌がみられるとされ ている. 職業性尿路腫瘍スクリーニング法としての尿 細胞診の有用性については広く知られている。この方 法により, 早期発見, 早期治療が行われ, 結果的に膀 脱保存症例が増光, 予後も比較的良好となっている.

われわれの経験した 32 例は, 6 つの染料工場で芳香 族アミンの製造，あるいは取扱いに従事していたが， 発生した腫瘍の病理所見, 臨床経過, 予後はさまざま である。比較的早期に悪性度の高い癌が進行し, 種々 の治療も効果なく死亡に至った症例(症例 $1 \sim 8,22$, $30 ， 31$ ), 特異な病理組織像を呈した症例(症例11，23） があれば，腫瘍発生は繰り返しているが， low grade tumor あるいはdysplasia, hyperplasia にとどまり， 経尿道的手術のみで予後良好な症例もある（症例 12 14，17～19，27，32). われわれはこの臨床像の違 いに注目し, その原因が各症例の体質の違いや発癌物 質以外の促進因子にあるのではなく, 労動環境や作業 内容, 寸なわち曝露量の差異にあるのではないかと考 えて検討をすすめた。従来の報告でも曝露期間や曝露 開始年齢々潜伏期間，腫瘍発生率との関係を検討した ものは比較的多くみられる。加野8) は曝露期間別によ る発病率を 5 年ごとに区切って計算し, 5 年以上曝露 した群で発病率が有意に高くなることを示した。さら に内藤ら ${ }^{3)}$ は, 曝露期間が長くなるにつれ発病率が上 昇する傾向をみとめている。森本ら ${ }^{5}$ は被曝開始年齢 が高くなるほど潜伏期間は短くなる傾向をみとめてい る. 作業内容と腫瘍発生率についての報告もみられ, 志岐9は $\mathrm{BZ}$ 製造作業者, 取扱い作業者に分けて, 製造 作業者に発生高率であることをみとめている，石津 ${ }^{10)}$ も同様製造作業が使用作業より高率と報告している 
が, $\operatorname{Scott}^{11)}$ は両者間に差がみられないとしている。中 村ら ${ }^{12}$ は, 症例の職業従事時に抢ける作業内容は配置 転換もあって一定しないため, 全て同様に取り扱った としている。

作業内容あるいは曝露状況と発生した腫瘍の病理組 織所見との関係について検討した報告はほとんどみら れていない，石津 $\left.{ }^{13}\right)$ は曝露期間が長くなると上皮内癌 や浸潤性の非乳頭状癌の発生が多くなると述べている が, 病理組織所見については言及していない。松島ら ${ }^{14)}$ は各症例の作業内容を製造，作業，配管工などに分け て詳細に報告しており, 曝露量はとの作業工程の環境 条件と個人の化学物質取扱いに対する衛生観念により 大きな差異を生ずると指摘しているが，発生した腫瘍 の病理組織所見, 予後と曝露状況との関係は明らかに していない.

従来の報告では曝露量の指標を曝露期間のみで検討 しているものが匡とんどであったが，曝露期間とは $\mathrm{BZ}, \beta \mathrm{NA}$ については，これにさらされる業務につい ていた期間ということになり, 労働環境や個々の作業 内容による暴露量の違いは全く考慮されていない。し たがって，同じ工程で作業に従事していた者の間では 曝露期間による比較検討は意味があるが，作業内容の 異なる者の間では注意を要すると思われる，山田ら ${ }^{15}$ は，職業性尿路上皮腫瘍102例を，製造に携わった曝露 者（直接者）と包装，運搬などの間接曝露者（間接者） に分け，発生した腫瘍の病理組織学的形態を比較検討 しているが，「直接者」「間接者」とも曝露期間が長く なると末分化型あるいは非乳頭状癌の頻度が高くなる こと, 癌の多発, 再発, 悪性進展例は複数の発癌物質 曝露や直接, 間接曝露あるいは複数回の曝露等の複雑 多岐な被曝露患者に多いことを報告している.

われわれは作業内容によって曝露量にかなりの違い があることを知り，曝露量の多い製造群と少ない取扱 い群の 2 群に分けて検討をすすめた結果，製造群には 有意に high grade 腫瘍の発生が多く, 死亡率も高いこ とが判明した。また，一部の症例であるが，製造群患 者の手術標本から flow cytometryにて作成した DNA ヒストグラムでは全て aneuploid patternがみ られ, 病理組織所見同様, 腫瘍細胞の性質がきわめて aggressive であることを示唆している.さらに詳しく みていくと, 重複癌の発生も全例製造群からであった。 職業性尿路腫瘍患者に重複癌の発生率が高いことは以 前から指摘されている．芳香族アミンを用いた動物の 発癌実験でも尿路以外の臓器の発癌性が実証されてお $\eta^{16)}$, 高濃度の発癌物質曝露により尿路以外の臟器で も腫瘍の発生率が上昇するものと考えられる。松島は 4 例の重複癌と 1 例の三重複癌を報告しているが，他 の報告で三重複癌以上の癌はみられていない，自験例 の五重複癌は現在までの報告では最も多い重複数のも のと思われる。経過観察中の症例に扐いても, 今後他 臟器癌発生に厳重な注意が必要であると考えられる。

上部尿路に特異な組織像を呈する腫瘍一癌肉腫と混 合型癌一が発生したのも製造群からであった。職業性 尿路腫瘍の病理組織学的診断はほとんどが移行上皮癌 で, 現在までに橘らの報告例の中に膀胱の腺癌が 1 例 みとめられるのみである。癌肉腫は悪性腫瘍の中に上 皮性成分と非上皮性成分が存在するきわめてまれな腫 瘍で，その組織発生については議論が多い。上部尿路 に打ける癌肉腫の報告は, きわめてまれであり, 職業 性尿路腫瘍患者の癌肉腫は現在まで報告されていな い.

Piscioli ら ${ }^{17)}$ ，Tajima ら ${ }^{18)}$ は，それぞれ，腎孟にみ られた肉腫様部分をもった腫瘍について免度組織化学 的検討を行い, keratin や EMA は陽性で vimentin や actin, desmin が陰性であったことから,この種の腫瘍 を上皮起源であると結論している. Wick ら ${ }^{199}$ は, 免度 組織化学的検討とともに, 電子顕微鏡による検討も行 い, 微細構造にも上皮性成分の特徵がみられたと報告 している.

症例23にみられた混合型癌の組織像は, 腺癌の一部 に移行上皮癌を伴っているもので, 従来の WHO 分類 では腺化生を伴ら移行上皮癌 variants of transitional cell carcinoma with glandular metaplasia とされて いたものである ${ }^{20)}$. その後米国の NBCP では治療と予 後判定との相関を検討するためにこのような type を 混合型癌 mixed carcinoma と表現し,化生といら語は 全く用いないようになっている21).わが国の膀胖癌取 扱い規約 ${ }^{22)} ゙$ は, 同一腫瑒の中に 2 種以上の組織型が 混在する場合には, 量的に優勢な組織型を主診断名と し, 他の組織型を付記, 優勢度を正確に記載すること になっている，混合型癌は通常悪性度の高い移行上皮 癌に伴らことが多いとされ，予後の不良なものが多く， 混在する組織型の占有率に関係なく，別に扱らことを 提案するものもいる ${ }^{23)}$.

以上のように，曝露が大量であったと考えられる製 造群の症例に怙いては, high grade の腫瘍発生が多い ことを始めとして, 発癌物質の dose-effect が現れてい るものと考えられる。 
動物実験では発癌物質の dose-effect がよく知られ て扮り, Okajima ら ${ }^{24)}$ は N-butyl-N-(4-hydroxybutyl)nitrosamine (BHBN) を使った犬の発癌実験 にて, 投与量が少ない時は異型度の低い, 表在性の腫 瘍が発生し，投与量が多いと異型度が高く，浸潤性の 腫瘍が発生する傾向があると報告している。.Oyasu $ら^{251}$ は，N-methyl-N-nitrosourea（MNU）を使った ラット膀胱の発癌実験で, 高濃度の MNU 投与によ $\eta$, high grade, high stage carcinoma の発生率が有 意に上昇したとして, 発癌物質の濃度は発生してくる 腫瘍の biologic aggresiveness の決定因子であると結 論している. また，これらのニトロソアミン類や N-4(5-nitro-2-furyl)-2-thiazolyl] formamide (FANFT) などで，まれに腺癌や未分化癌, 癌肉腫, 血管肉腫, 線維肉腫などの発生も知られている2627). 最近これら 発癌物質の機序が尿路上皮粘膜における DNA の直接 損傷と考古られている ${ }^{28)}$. 芳香族アミンの発癌機序に ついては古くから ortho-hydroxylation 説, Nhydroxylation 説が知られているが，いずれにしても 代謝産物による粘膜の DNA 損傷が発癌の引きがねに なっていることは間違いなく29), 高濃度曝露群に発生 した異型度の高い腫瘍や特異な組織像を示す腫瘍は, 動物実験におけるニトロソアミン類やFANFTなど と同様に dose-effect が臨床症例に発現したものと考 えられる。したがって，製造に従事した者には今後も 他藏器をも含めて, 特に厳重な経過観察が必要と思わ れる。製造群の中には, 膀脱保存を目的として経尿道 的手術や膀胱部分切除術を繰り返し施行したところ, 再発とともに異型度が上昇し, 膀胼全摘除術を施行し たが予後不良であった症例も数例あった。これらの症 例では早期に膀胱全摘除術を施行していれば生存の可 能性もあったのではないかと反省させられる。一方， 取扱い群では，今後も low grade tumorあるいは dysplasia, hyperplasia が繰り返し発生するものと予 想され，その治療方針は引き続き膀胼保存的に行らべ きであろらと思われる。最近われわれの教室では, dysplasia がみとめられた症例に対して化学療法剤の 動脈内注入を行い, 腫瘍発生の予防を試みている。職 業性膀胼腫瘍患者で臨床的に明確な腫瘍を形成する前 段階として carcinoma in situ の病態を示すことが知

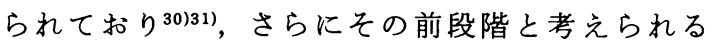
dysplasia に対して積極的にアプローチすることは再 発予防を考える上で重要なことと思われる。

$\mathrm{BZ}, \beta \mathrm{NA}$ などのような強力な発癌物質による職業
癌の発生は将来 2 度と起こることはないと思われる が, 現在われわれが住んでいる生活環境の中にはおび ただしい数の化学物質が存在し，それらを体内に取り 入れる機会も増加しつつある. 今後, これら化学物質 の発癌性を厳重に監視するとともに，種々の職業につ いて疫学的に検討をす寸める必要があると考えられ る.

\section{結語}

当教室で経験した職業性尿路腫場32例について臨床 的検討を行った．各症例の曝露状況と発生した腫瘍の 異型度, 予後との間には重要な関連があり，発癌物質 の dose-effect のあらわれと考えられた。

稿を終えるにあたり，御指導を賜った徳汇章彦教授，恩 師，故米瀬泰行教授に深く感謝致します。

なお，本論文の要旨は，第78回日本泌尿器科学会総会(札 幌，1990）および第 1 回アジア泌尿器科学会（福岡，1990） にて発表した。

\section{文献}

1) Rehn, L.: Blasengeschwulste bei Anilinarbeitern. Arch. Klin. Chin. Chir., 50, 588-600, 1895.

2) Hueper, W.C.: Occupational and Environmental Cancers of Urinary System. 118-140, New Heaven and London, Yale, 1969.

3）内藤誠二, 熊澤浄一：芳香族アミン化合物による 尿路腫瘍。泌尿紀要，35，2023-2031，1989.

4）板谷宏疣：職業と尿路腫場一その背景々臨床像 一。泌尿紀要， 35，2011-2014， 1989.

5）森本鎮義, 上門康成, 青枝秀男, 平野敦之, 新家俊 明, 大川順正, 藤永卓治, 中村 順：職業性尿路腫 陽：和歌山市における現況々臨床的検討。泌尿紀 要, 35, 2015-2022, 1989 .

6）橘 政昭,田崎 寛, 村井 勝, 山口直人：職業性 尿路腫場の背景と現況. 泌尿紀要, 35, 2003-2009, 1989.

7）松島正浩：職業性膀胱癌：スクリーニング開始後 20 年間における臨床成績とその予後。泌尿紀要, 35, 2033-2040, 1989.

8）加野資典：芳香族了ミン化合物による尿路上皮腫 瘍の臨床統計学的研究. 西日泌尿, 47, 1665-1680, 1985.

9）志岐太一郎：Benzidine に上る職業性尿路系腫瘍 の発生に関する労動衛生学的研究. 久留米医会誌, 33, 363-387, 1970.

10）石津澄子：尿細胞診による職業性膀胖腫瘍の管 理. p. 1-15, 化成品工業協会, 東京, 1975 .

11) Scott, T.S.: Carcinogenic and Chronic Toxic Hazards of Aromatic Amines. Elsevier Publishing Company, Amsterdam-New York, 1962. 
12）中村 順，高松正人，土居 淳，大川順正，藤永卓 治, 我野庄一, 曽根正典：和歌山市における職業性 尿路腫瘍に関寸る臨床的検討. 日泌尿会誌, 71 , 945-951，1980.

13）石津澄子：職業性膀腅がんの歴史と展望。日災医 誌， 36，356-360， 1988.

14）松島正浩, 村上憲彦, 深沢 潔, 柳下次雄, 藤尾幸 司, 三浦一陽, 沢村良勝, 田島政晴, 中山孝一, 白 井将文, 安藤 弘：職業性膀脱癌. スクリーニング 開始後 15 年間における臨床成績とその意義. 日泌 尿会誌，74，81-99，1983.

15）山田 喬, 石津澄子：発癌物質に対する曝露条件 から分析した職業性尿路上皮癌の悪性度. Proceedings of the Japanese Cancer Association, 237, 48th Annual Meeting October, 1989, Nagoya.

16) Clayson, D.B.: Occupational bladder cancer. Preventive Med., 5, 228-244, 1976.

17) Piscioli, F., Bondi, A., Scappini, P. and Luciani, L. : "True" sarcomatoid carcinoma of the renal pelvis. Eur. Urol., 10, 350-355, 1984.

18) Tajima, Y. and Aizawa, M.: Unusual renal pelvic tumor containing transitional cell carcinoma, adenocarcinoma and sarcomatoid elements (so-called sarcomatoid carcinoma of the renal pelvis). Acta Pathol. Jpn., 38, 805-814, 1988.

19) Wich, N.R., Perrone, T.L. and Burke, B.A.: Sarcomatoid transitional cell carcinomas of the renal pelvis: An ultrastructural and immunohistochemicalstudy. Arch. Pathol. Lab. Med., 109, 55-58, 1985.

20）伊東信行：膀脂腫瘍の組織分類。臨泌，37, 101-107, 1983.

21) Friedell, G.H.: Histopathology and classification of urinary bladder carcinoma. Urol. Clin. N. Am., 3, 53-70, 1976.

22) 泌尿器科 - 病理. 膀胖癌取扱い規約, 日本泌尿器
科学会・日本病理学会編, 金原出版, 1980, p. 61一 88.

23) Murphy, W.M.: Diseases of the Urinary Bladder, Urethra, Ureters and Renal Pelvis. "Urological Pathology" W.B. Saunders Company 1989 , p. 87.

24) Okajima, E., Hiramatsu, T. and Hirano, K.: Urinary bladder tumors induced by N-butyl-N84-hydroxybutyl) nitrosamine in dogs. Cancer Res., 41, 1958-1966, 1981.

25) Oyasu, R., Samma, S. and Ozono, S.: Induction of high-grade, high-stage carcinomas in the rat urinary bladder. Cancer, 59, 451-458, 1987.

26) Tiltman, A.J. and Friedell, G.: The histogenesis of experimental bladder cancer. Invest. Urol., 9, 218-226, 1971.

27) Fukushima, S., Hirose, M., Tsuda, H. and Ito, N. : Histological classification of urinary bladder cancers in rats induced by N-butyl-N-(4hydroxybutyl) nitrosamine. Gann, 67, 81-90, 1976.

28) Cox, R. and Irving, C.C.: Effect of N-methyl$\mathrm{N}$-nitrosourea on the DNA of rat bladder epitherium. Cancer Res., 36, 4114-4118, 1976.

29) McQueen, C.A., Barbara, M.W. and Williams, G.M.: Biotransformation of aromatic amines to DNA-damaging products by urinary bladder organ cultures. Carcinogenesis, 8, 401-404, 1987.

30) Koss, L.G.: Carcinogenesis in the human urinary bladder. Observations after exposure to para-aminodyphenyl. N. Engl. J. Med., 272, 767-770, 1965.

31) Schade, R.O.K. and Swinney, J.: Precancerous changes in bladder epitherium. Lancet, 2, 943-946, 1968.

（1991年 3 月 15 日受理，特別揭載） 